\title{
悉皆アンケート調査からみた東日本大震災における 高齢者施設の被災実態および復旧状況に関する考察 \\ ANALYSIS ON THE DAMAGE AND RECOVERY AT FACILITIES FOR THE ELDERLY DUE TO THE GREAT EAST JAPAN EARTHQUAKE BY QUESTIONNAIRE SURVEY
}

\author{
神吉優美*, 井上由起子**, 石井 敏***
}

\section{Yumi KANKI, Yukiko INOUE and Satoshi ISHII}

\begin{abstract}
According to a questionnaire survey of the facilities for the elderly in Miyagi and Iwate, 95.4\% of them suffered building and site damage. Tsunami had a greater impact than earthquake intensity. 31 facilities were struck by tsunami, and elderly were killed or missing at eight of them. The high percentage of tsunami attacks on small-sized multifunctional in-home care linked to the high percentage of "completely destroyed" . Land development was linked to site damage. 63.0\% of nursing homes and health services facilities for the aged had developed lands, and these were linked to the high percentage of site damage.
\end{abstract}

Keywords: Great East Japan earthquake, Facilities for the elderly, Questionnaire survey, Damage situation, Recovery situation, Disaster prevention plan 東日本大震災，高齢者施設，アンケート調査，被災状況，復旧状況，防災計画

\section{1. 研究の背景と目的}

東日本大震災は高齢者施設にも甚大な被害をもたらした。岩手、宮 城、福島の 3 県における高齢者施設で全壊・半壊判定を受けた施設が 52 施設あり、入居者 485 名、職員 173 名が死亡・行方不明となって いる注1)。

また、人的な被害や建物被害に加え、長期にわたるライフラインの 断絶、燃料不足等により、事業の継続に際して極めて深刻な事態に 陥った施設、現地での事業継続が困難で他施設や他県に集団避難せざ るを得ない状況に陥った施設等、各施設が直面した状況はこれまでの 災害で例が無いほどの厳しいものとなった。

本研究は、宮城県および岩手県に位置する高齢者施設を対象とした 悉皆アンケート調查に基づき、高齢者施設における建築設備面・ソフ 卜面の被災の実態、復旧状況、防災計画の全体像を明らかにし、今後 の高齢者施設の防災計画や将来の施設計画に資するための基礎的知 見を得ることを目的としている。

東日本大震災の被災実態に関する調查研究が各分野で実施されて いる。被災した施設および被災者を受け入れた施設を対象とした調査 から特養等における被災状況と支援体制について明らかにした研究 2)、被苂直後から復旧、復興、再生・自立までの各段階における適切 な支援のあり方に関する研究 ${ }^{3)}$ 、認知症高齢者グループホーム（以下、 認知症 GH）における災害対策の考え方について実践例も交えて言及
した研究報告 ${ }^{4)}$ 、高齢者施設を含めた福祉施設の立地特性と被災状況 について明らかにした研究 ${ }^{5)}$ 等がなされている。しかし、1995 年の 阪神・淡路大震災を含め、災害時の高齢者施設の被災の実態を八ー ド・ソフト両面において網羅的に明らかにした研究はこれまでにな く、本研究は今後の高齢者施設の防災計画を検討する上で意義が高 いと考えられる。

\section{2. 調査の方法}

調查対象は、岩手県ならびに宮城県に位置する老人保健施設（以下、 老健）、特別養護老人ホーム (以下、特養)、認知症 GH、小規模多機 能型居宅介護（以下、小規模多機能）である。福島県については原 子力発電所事故の影響を踏まえ、調査を自肃した。岩手県について は 2011 年 9 月 1 日現在のデータ（岩手県保健福祉部長寿社会課から の提供)、宮城県については 2011 年 3 月 1 日現在のデータ（宮城県 保健福祉部からの提供）に基づき、両県の当該施設に対して悉皆調 查を実施した。アンケート票を郵送配布・留置・郵送回収した。調 查期間は 2011 年 10 月〜 11 月である。調査項目は施設概要、建物性能、 被災状況、再建計画、ライフラインと各種設備、防災計画と備蓄計 画など全 59 項目に及ぶ。震災後に事業の廃止が確認された岩手県の 2 施設（老健 1 施設、認知症 GH1 施設）は提供されたデータから削除 されていたため、調査から除外した。震災後に事業の廃止が確認さ

\footnotetext{
本稿は，2012年度建築学会大会学術講演会 PD の梗概 ${ }^{6}$ を加筆・修正したものである。 東洋大学ライフデザイン学部人間環境デザイン学科 Assoc. Prof., Toyo Univ., Dr. Eng. 准教授·博士 (工学)

** 日本社会事業大学専門職大学院 准教授・博士(工学)

*** 東北工業大学工学部建築学科 教授・博士 (工学) 
れた宮城県の 4 施設（老健 1 施設、特養 2 施設、小規模多機能 1 施設） にはアンケート票を配布し、小規模多機能 1 施設から回答が得られた。

配布数と回答数を表 1 に示す。786 施設にアンケート票を配布し、 回答数は 536 施設（回答率 $68.2 \%$ )、有効回答数は 504 施設（有効回 答率 $64.1 \%$ ）である。有効回答数の内訳は、老健 $17.7 \%$ (89 施設)、 特養 33. 9\% (171 施設)、認知症 GH39.7\%（200 施設）、小規模多機能 8.7\% (44 施設) である。県別・沿岸内陸別回答数を図 1 に示す。宮城県 273 施設 $(54.2 \%)$ 、岩手県 231 施設 $(45.8 \%)$ であり、内陸部市町村 338 施設 (67.1\%)、沿岸部市町村 166 施設 $(32.9 \%)$ である注 2$)$ 。

なお本稿では割合を小数点以下第二位を四捨五入して表記してい るため、本文の数值と図表データの合算值が一致しない場合がある。

\section{3. 施設概要}

\section{1 ) 事業概要}

各施設の平均の定員規模は老健 99.3 床、特養 72.6 床、認知症 GH13. 8 床、小規模多機能 24.0 名（登録定員）であった。

事業年数は、「10 年未満」のものが老健 $30.3 \%$ 、特養 $31.6 \%$ 、認知 症 GH85.5\%、小規模多機能 100\% であった（図 2)。建物整備に伴う借 入金の返済が終わってない施設が一定程度あることが推察される。

\section{2) 建物概要}

建物の性能は建物被害や事業再建に関連してくると予測される。老 健と特養、認知症 GH と小規模多機能で建築性能が異なることを確認 しておく(表 2)。

\section{【延床面積・階数】}

老健と特養は「1, $000 \mathrm{~m}^{2}$ 以上」が $93.8 \%$ であるのに対し、認知症 $\mathrm{GH}$ と小規模多機能は「 $1,000 \mathrm{~m}^{2}$ 未満」が $85.2 \%$ を占める。関連して「平屋」 は老健と特養で $42.7 \%$ 、認知症 $\mathrm{GH}$ と小規模多機能で $68.0 \%$ であった。

\section{【構造・耐震性能】}

老健と特養は「RC 造」が $82.8 \%$ 、認知症 $\mathrm{GH}$ と小規模多機能は「木 造」が $73.8 \%$ であった。新耐震基準もしくはそれに準ずる性能（耐震

表 1 アンケート調査の回答状況

\begin{tabular}{|c|r|r|r|r|r|}
\hline & \multicolumn{1}{|c|}{ 全体 } & \multicolumn{1}{c|}{ 老健 } & \multicolumn{1}{c|}{ 特養 } & 認知症 $\mathrm{GH}$ & 小規模多機能 \\
\hline 配布数 & 786 & 142 & 230 & 346 & 68 \\
\hline 回答数 & 536 & 92 & 178 & 218 & 48 \\
\hline 有効回答数 & 504 & 89 & 171 & 200 & 44 \\
\hline 有効回答率 & $64.1 \%$ & $62.7 \%$ & $74.3 \%$ & $57.8 \%$ & $64.7 \%$ \\
\hline 割合 : 配布 & $100.0 \%$ & $18.1 \%$ & $29.3 \%$ & $44.0 \%$ & $8.7 \%$ \\
\hline 割合: 有効回答 & $100.0 \%$ & $17.7 \%$ & $33.9 \%$ & $39.7 \%$ & $8.7 \%$ \\
\hline
\end{tabular}

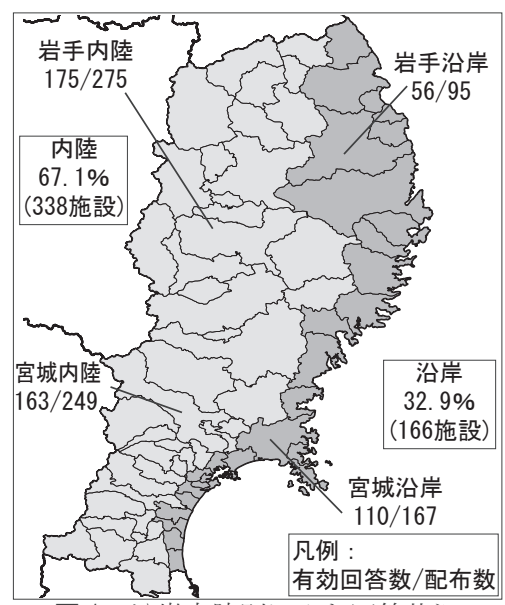

図 1 沿岸内陸別にみた回答状況
補強完了）の建物は老健と特養で $81.2 \%$ 、認知症 GH と小規模多機能 で $58.2 \%$ であった。ただし後者は「不明」との回答が $30 \%$ を超えている。

\section{【建て方】}

老健と特養は「新築型」が $99.2 \%$ である。認知症 GH と小規模多機 能は「新築型」が $81.8 \%$ であり、その分「転用型」が多い。

\section{【土地造成】}

老健と特養は「盛り土」が $36.9 \%$ 、「切り土」が $19.2 \%$ 、「盛り土と 切り土」が $6.9 \%$ であり、「土地造成なし」は23.8\%であった。これに 対し、認知症 GH と小規模多機能は「土地造成なし」が $41.0 \%$ であった。

\section{4. 被災の状況}

\section{1) 震度}

「震度 $7 」 13.3 \%$ 、「震度 6 強」35. 5\%、「震度 6 弱」27.8\%、「震度 5 強」 18. $7 \%$ 、「震度 5 弱」 $3.6 \%$ 、「震度 4 以下」 $1.2 \%$ であった。震度 6 以上 が $3 / 4$ を占める。沿岸部の市町村では震度 6 強以上の割合が高い（図 3)。施設種別による大きな違いはない。

\section{2) 津波}

504 施設の内「津波被害あり」は 31 施設 $(6.2 \%)$ であった注3)。沿 岸部市町村に限ってみると $18.7 \%$ にあた、これをさらに施設種別 でみると小規模多機能で $42.1 \%$ (8 施設 ) と最も割合が高く、認知症 GH18. 8\% (12 施設) 、特養 14.8\%(8 施設)、老健 $10.3 \%$ (3 施設) であっ た（図 4)。小規模多機能で割合が高いのは、民家が多くあるまちな かに立地していたためと推察される。

31 施設の内訳は床下浸水が 3 施設、1 階床上浸水が 16 施設、2 階 以上床上浸水が 12 施設であった。
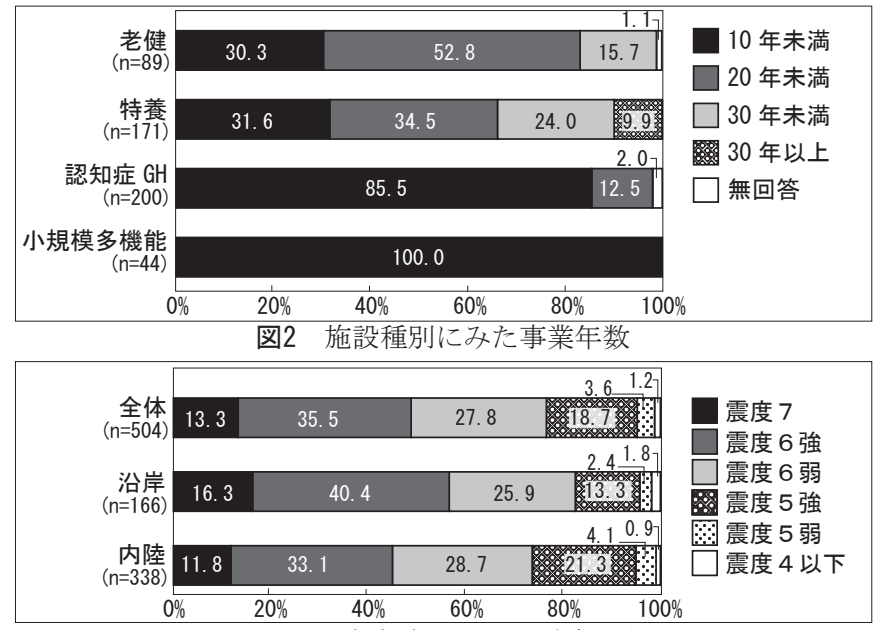

図 3 沿岸内陸別にみた震度分布

表 2 建物概要

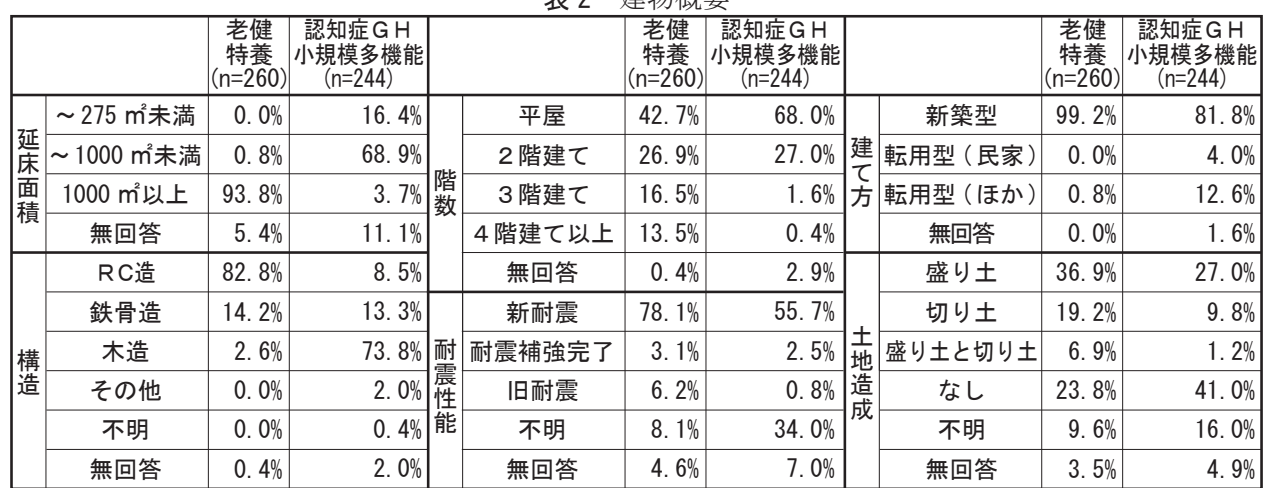




\section{3) 火災}

火災が発生したのは特養の 1 施設のみであった。津波により建物が 浸水し、配電盤ショートによる火災が発生し、消火器にて鎮火した。

\section{4 ) 人的被害}

利用者のみに人的被害（死亡・行方不明）があった施設は 1 施設、 職員のみに被害があった施設が 4 施設、双方に被害があった施設が 7 施設であり、合計 12 施設で人的被害があった。沿岸部市町村に位置 する 166 施設の $7.2 \%$ にたる。県別では、宮城県 10 施設、岩手県 2 施設、施設種別では特養 6 施設、認知症 GH3 施設、小規模多機能 2 施設、 老健 1 施設であった (表 3 )。

利用者に被害のあった 8 施設全てが床上浸水の被害を受けていた。 職員のみに被害のあった 4 施設に津波の被害はなく、発災当時に建物 内におらず、地域で津波にあったものと推察される。

\section{5. 建物被害と建物再建}

1) 被害状況

建物被害状況を図 5 に示す。「建物被害なし」は $4.6 \%$ にすぎず、 95. $4 \%$ の施設に何らかの建物被害があった。「建物内の亀裂・落下」 $50.2 \%$ 、「外壁の亀裂」 $40.3 \%$ 、「建具や家具の破損」 $35.5 \%$ 、「屋内設備
の破損」31. 3\%、「地盤被害」 $29.6 \%$ 、「屋外設備の破損」 $28.2 \%$ 、「構造 体の被害」9.5\%、「スプリンクラー ( 以下、SP) 誤作動放水」 $1.8 \%$ であっ た。

「地盤被害」は土地造成と関連性がみられた（図 6)。「盛り土」し た施設の $46.3 \%$ 、「盛り土+切り土」した施設の $61.9 \%$ で地盤被害が あり、被害が顕著である。

施設種別の被害状況をみる。「地盤被害」が老健 $44.9 \%$ 、特養 $40.4 \%$ に対して認知症 GH16. 5\%、小規模多機能 $15.9 \%$ であり、2 倍 以上の開きがあった（図 7)。土地造成は老健や特養で多くなされて いることが影響していると推察される(表 2 参照)。「外壁の亀裂」「屋 外設備の破損」、「屋内設備の破損」についても老健と特養での被害の 割合が高い。「構造体の被害」については、津波被害の割合の高い小 規模多機能が $18.2 \%$ と最も高い。

津波の有無によって建物被害は顕著に異なる。「構造体の被害」は 「津波なし」5.5\%に対して、「津波あり」71.0\%と 13 倍の開きがあった。 「屋外設備の破損」「屋内設備の破損」では 3 倍以上、「地盤被害」「「建 具や家具の破損」では 2 倍以上の開きがあった（図 8)。

津波の被害のなかった施設について、建物被害状況についてみる。 「震度 6 以上」の施設は「震度 5 以下」の施設に比べて被害が大きく、「地

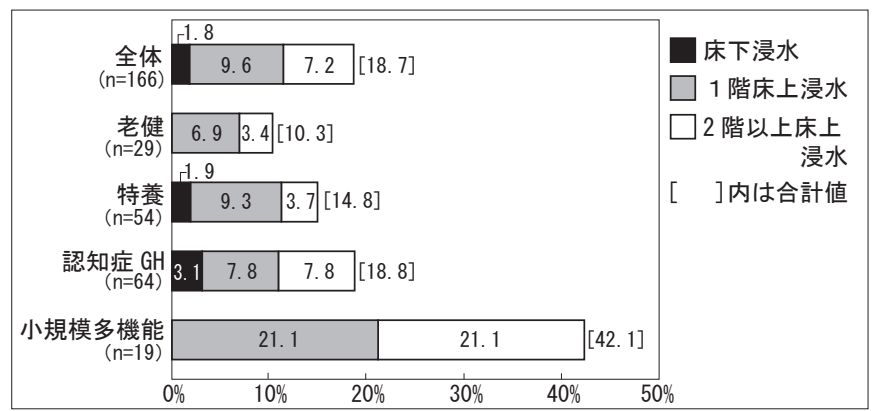

図 4 施設種別にみた津波の有無（沿岸部市町村）

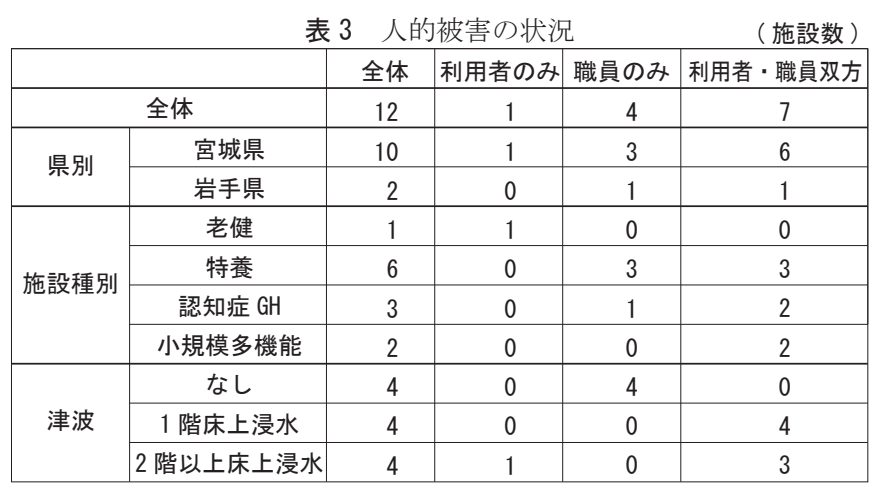
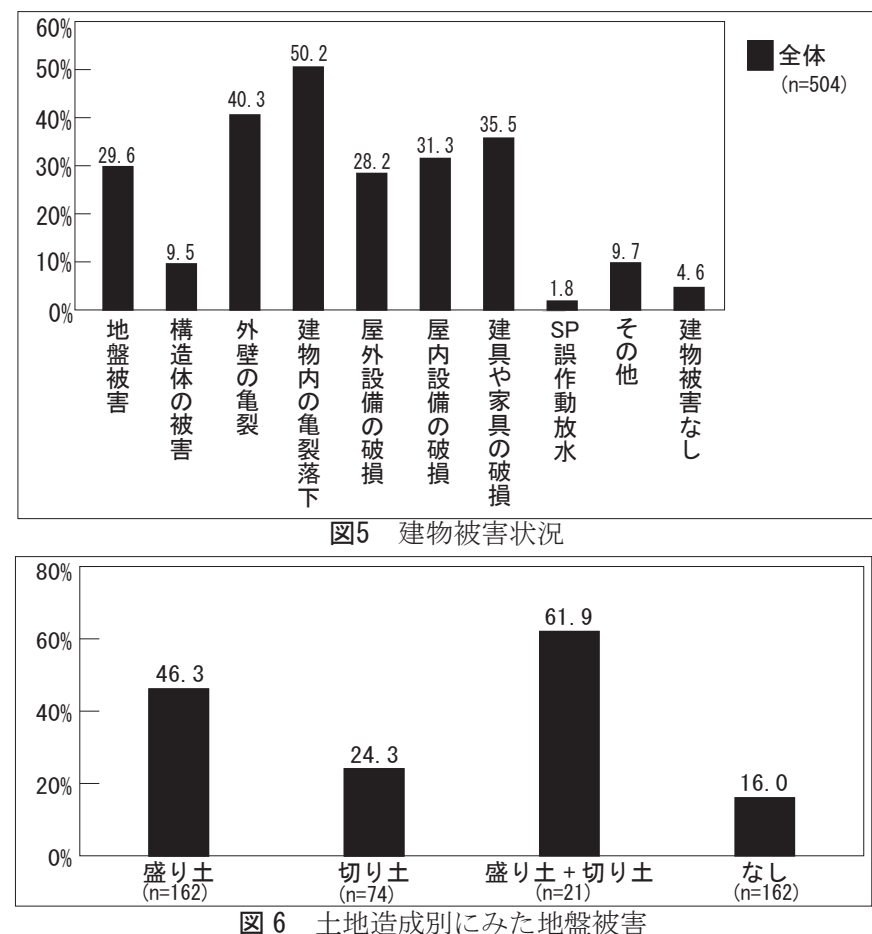

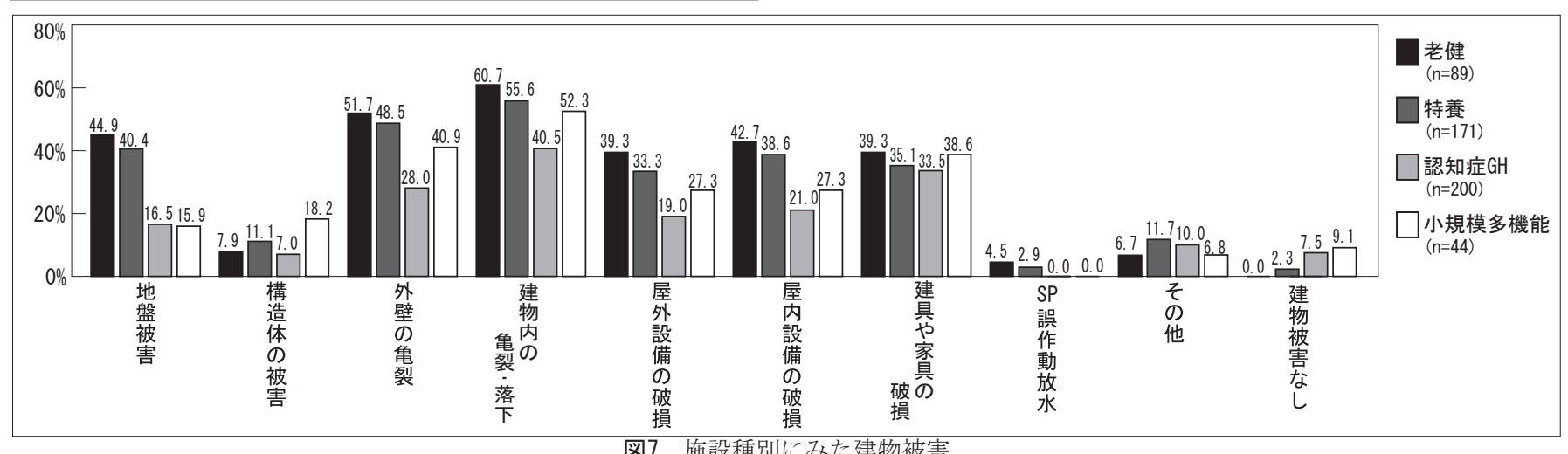


盤被害」では 4 倍以上、「構造体の被害」「屋外設備の破損」、「建具 や家具の破損」では 3 倍以上、「外壁の亀裂」「屋内設備の破損」で は 2 倍以上の開きがあった（図 9)。老健および特養において震度に よる建物被害の差が大きく、特に「地盤被害」、「外壁の亀裂」「「屋外 設備の破損」において開きが大きい（表 4)。

「構造体の被害」は建物の構造、耐震性能、建て方のいずれとも関 連性がなかった。

\section{2 ) 被害判定}

全壊もしくは半壊と判定された施設を地図上に示寸 (図 10)。

「全壊」4.4\% (22 施設)、「半壊」3. 6\% (18 施設)、「一部損壊」28.4\% (143 施設)、「該当せず」59.7\%(301 施設)であった（図 11)。「津波被害あり」 の 31 施設についてみると、「全壊」 $71.0 \%$ 、「半壊」 $16.1 \%$ 、「一部損 壊」 $6.5 \%$ 、該当せず」 $3.2 \%$ であり、「全壊」または「半壊」で 9 割 近くを占める。津波被害のなかった施設で「全壊」判定を受けた施設 はなかった。「震度 6 以上」では 4 割近くが「半壊」または「一部損壊」

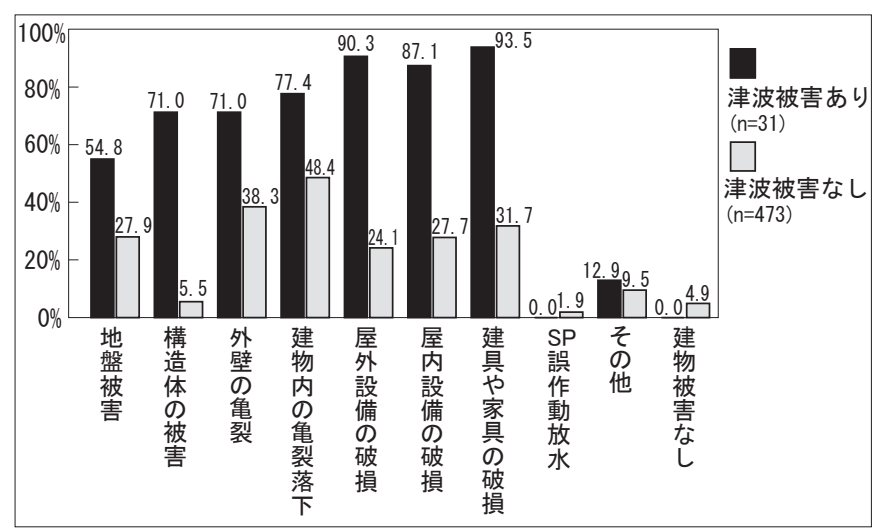

図8＼cjkstart津波の有無別にみた建物被害

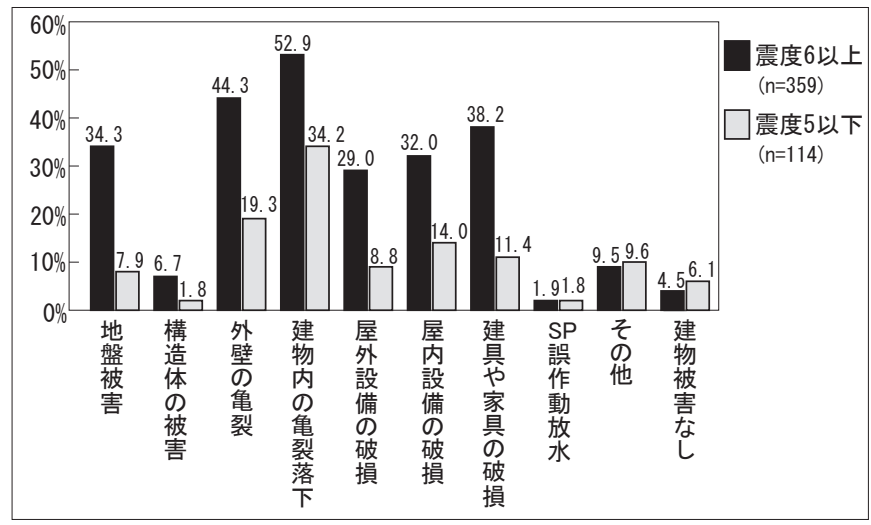

図9 震度別にみた建物被害

表 4 施設種別・震度別にみた建物被害

\begin{tabular}{|c|c|c|c|c|c|c|c|c|}
\hline & \multicolumn{2}{|c|}{ 老健 } & \multicolumn{2}{|c|}{ 特養 } & \multicolumn{2}{|c|}{ 認知症 GH } & \multicolumn{2}{|c|}{ 小規模多機能 } \\
\hline & $\begin{array}{c}\text { 震度 } \\
6 \text { 以上 }\end{array}$ & \begin{tabular}{|c|} 
震度 \\
以欠下
\end{tabular} & $\begin{array}{l} \\
6 \text { 震度 } \\
\end{array}$ & 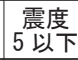 & $\begin{array}{c} \\
6 \text { 震度 } \\
6 \text { 以上 }\end{array}$ & $\begin{array}{c}\text { 震度 } \\
5 \text { 以下 }\end{array}$ & $\begin{array}{c}\text { 震度 } \\
6 \text { 以上 }\end{array}$ & $\begin{array}{c}\text { 震度 } \\
5 \text { 以下 }\end{array}$ \\
\hline 地盤被害 & 52.3 & 19.0 & 49.6 & 11.4 & 17.3 & 0.0 & 16. 0 & 0.0 \\
\hline 構造体の被害 & 7. 7 & 4. 8 & 10.9 & 0.0 & 3.3 & 0.0 & 4. 0 & 9.1 \\
\hline 外壁の亀裂 & 61.5 & 19.0 & 56.3 & 22. 7 & 28. 7 & 10.5 & 36.0 & 36.4 \\
\hline 建物内の亀裂落下 & 70.8 & 33.3 & 58.8 & 43. 2 & 40.7 & 23.7 & 52.0 & 36.4 \\
\hline 屋外設備の破損 & 46. 2 & 9.5 & 37.0 & 11.4 & 17.3 & 5.3 & 16. 0 & 9. 1 \\
\hline 屋内設備の破損 & 46.2 & 28.6 & 42.0 & 20.5 & 20.0 & 2.6 & 20.0 & 0.0 \\
\hline 建具や家具の破損 & 46.2 & 9.5 & 37.8 & 18. 2 & 34.7 & 7.9 & 40.0 & 0.0 \\
\hline SP 誤作動放水 & 4. 6 & 4. 8 & 3. 4 & 2. 3 & 0.0 & 0.0 & 0.0 & 0.0 \\
\hline その他 & 6.2 & 9.5 & 10.9 & 13. 6 & 10.0 & 7.9 & 8.0 & 0.0 \\
\hline 建物被害なし & 0.0 & 0.0 & 0.8 & 6.8 & 7.3 & 10.5 & 16.0 & 0.0 \\
\hline
\end{tabular}

であるのに対し、震度 5 以下」では「該当せず」が 8 割以上を占める。 全壊判定を受けた 22 施設の内訳は老健 1 施設、特養 6 施設、認知症 GH8 施設、小規模多機能 7 施設であった。認知症 GH は 8 施設の全て が木造、小規模多機能は 7 施設のうち 5 施設が木造であった。全壊し た全 22 施設が津波被害を受けており、津波被害の割合が高かった小 規模多機能において「全壊」の割合が高い（図 12）(図4 参照)。

「全壊」 22 施設は全て津波の被害を受け、「半壊」18 施設は「津波 被害あり」が 5 施設、「津波被害なし」が 13 施設であった。13 施設 の内訳をみると、施設種別による偏りはなく、新耐震基準もしくはと れに準ずる性能（耐震補強完了）の建物が 9 施設、「不明」が 3 施設、 「無回答」が 1 施設であり、震度は震度 7 が 2 施設、震度 6 強が 9 施設、 震度 6 弱が 2 施設であった。

\section{3 ) 事業継続}

全壊した 22 施設の被災後の事業継続をみると、「事業継続」 8 施設、 「一旦休止後事業再開」 7 施設、「事業休止」 6 施設、「事業廃止」 1 施
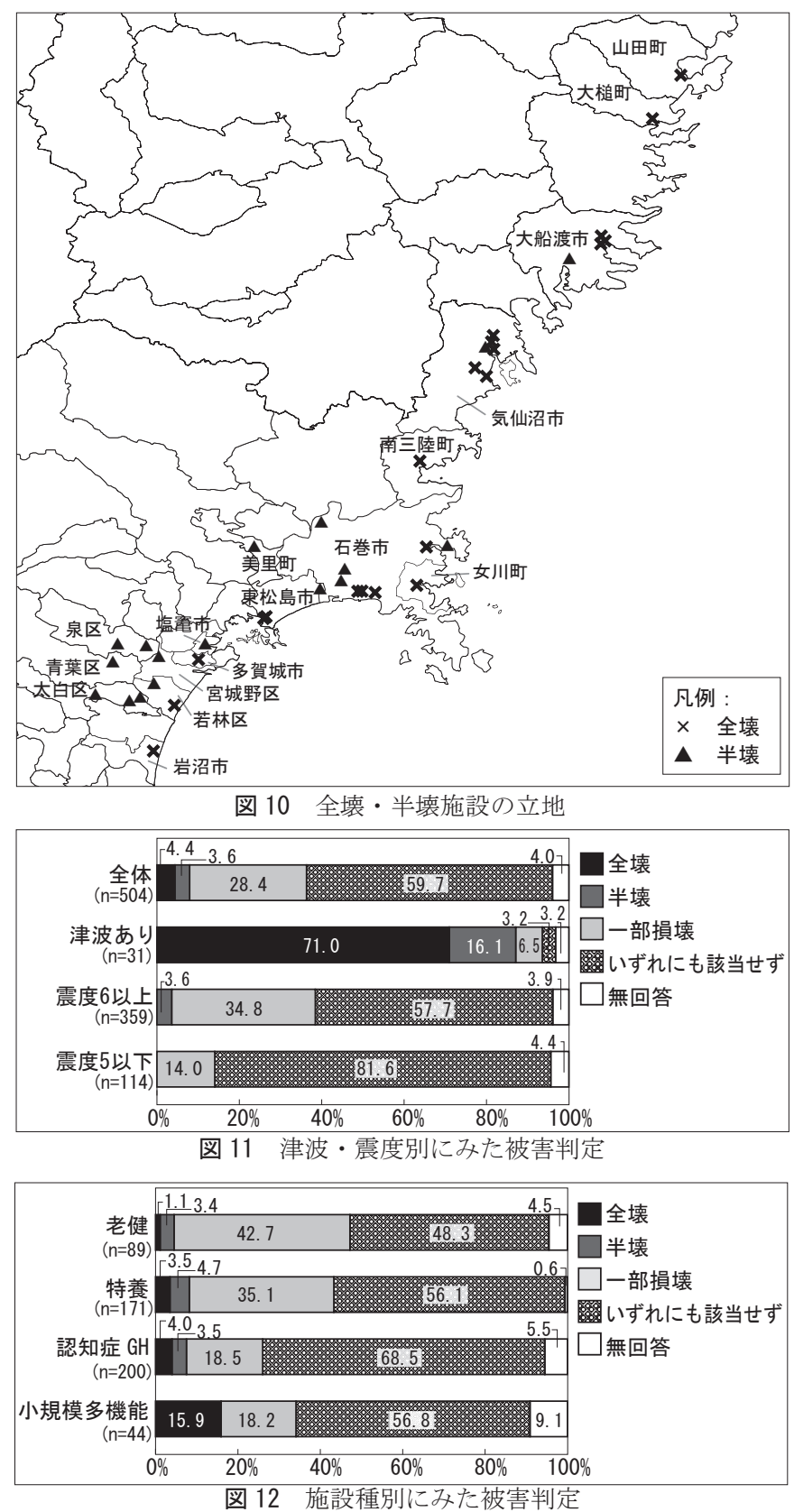
設であった（図 13）。「事業廃止」の1施設（小規模多機能）は津波 により利用者と職員の双方に人的被害があった。この 1 施設を除く 21 施設の内、20 施設は建替えの意向であり、残り 1 施設は現時点で は事業は継続しているが、今後再建するか否かは無回答であった。

全壊を逃れた 482 施設は、継続して元の建物を利用している施設が 大半を占めた。別敷地の法人関連の建物を利用している施設、行政が 用意した建物を利用している施設は、それぞれ 2 施設であった。これ ら 482 施設の今後の予定は、「元の建物を利用」 $81.5 \%$ (393 施設)、「建 替え」 $1.2 \%$ (6 施設 )、「無回答」 $17.2 \%$ (83 施設) であった。

全壊で建替えによる事業再建を予定している 20 施設のほか、半壊 および一部損壊で建替えを予定している施設が 6 施設あった。再建に 向けた課題として、土地確保（建築制限による代替地確保、市街化調 整区域での開発行為）および建替え資金（土地高騰による購入費、既 借入と併せた二重返済）があげられた。また、事業休止中の施設から は、再建までの職員の雇用維持も課題としてあげられた。

\section{6. ライフラインの停止と復旧}

全壊判定を受けた 22 施設を除く 482 施設におけるエネルギー源を 確認した上で、ライフラインの停止および復旧状況についてみる（図 14)。

1) 各施設のエネルギー源

【厨房】

「電気」33.8\% (163 施設) 、「ガス」34.6\% (167 施設)、「併用」28.6\%(138 施設 ) であった。老健と特養では「ガス」と「併用」が多く、認知症 $\mathrm{GH}$ と小規模多機能では「電気」が多い。

\section{【給湯】}

「石油」35.7\% (172 施設)、「ガス」22.2\% (107 施設)、「電気」16.2\% (78 施設 ) であった。認知症 $\mathrm{GH}$ や小規模多機能では「ガス」や「電気」 を利用する施設も多い。

\section{【空調】}

「電気」54.4\% (262 施設) 、「石油とガス」 18.5\% (89 施設 )、「石油」 $14.1 \%(68$ 施設 $)$ であった。認知症 GH と小規模多機能で「電気」が多い。

\section{【ガスの種類】}

「都市ガス」10.4\% (50 施設)、「プロパンガス」 $64.5 \%$ (300 施設)、「併 用」0.4\%（2 施設）、「ガス使用なし（オール電化）」21.4\%（103 施設 ） であった。老健と特養では「プロパンガス」が $70 \%$ を超える。認知症 $\mathrm{GH}$ と小規模多機能においても「プロパンガス」が過半を占めるが、「ガ ス使用なし」が認知症 $\mathrm{GH}$ で 37. $0 \%$ （71 施設 )、小規模多機能で $27.0 \%$ (10 施設 ) であり、オール電化の施設も多い（図 15)。

\section{2 ) ライフラインの停止と復旧状況}

図 16 にライフラインの停止状況、図 17 にライフラインの復旧状況、 表 5 に「津波被害あり」、「震度 6 以上」「震度 5 以下」別にみた復旧 までに要した平均・最短・最長日数をみる。

\section{【電気】}

482 施設の内 475 施設 $(98.5 \%)$ で停電した。復旧までに要した日数 は平均で 5.6 日であった。 3 日後には約半数の施設で、一週間後には 83. $8 \%$ の施設で復旧した。停止率は全ライフラインの中で最も高いが、 平均復旧日数は最も短かった。

平均復旧日数をみると、「津波被害あり」 23.0 日、「震度 6 以上」 6.1 日、「震度 5 以下」2.8 日であり差が大きい。

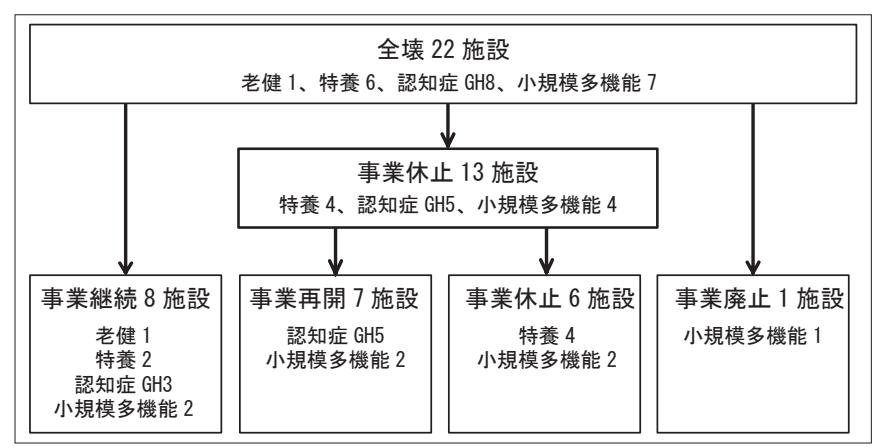

図 13 全壊判定施設の事業継続の状況

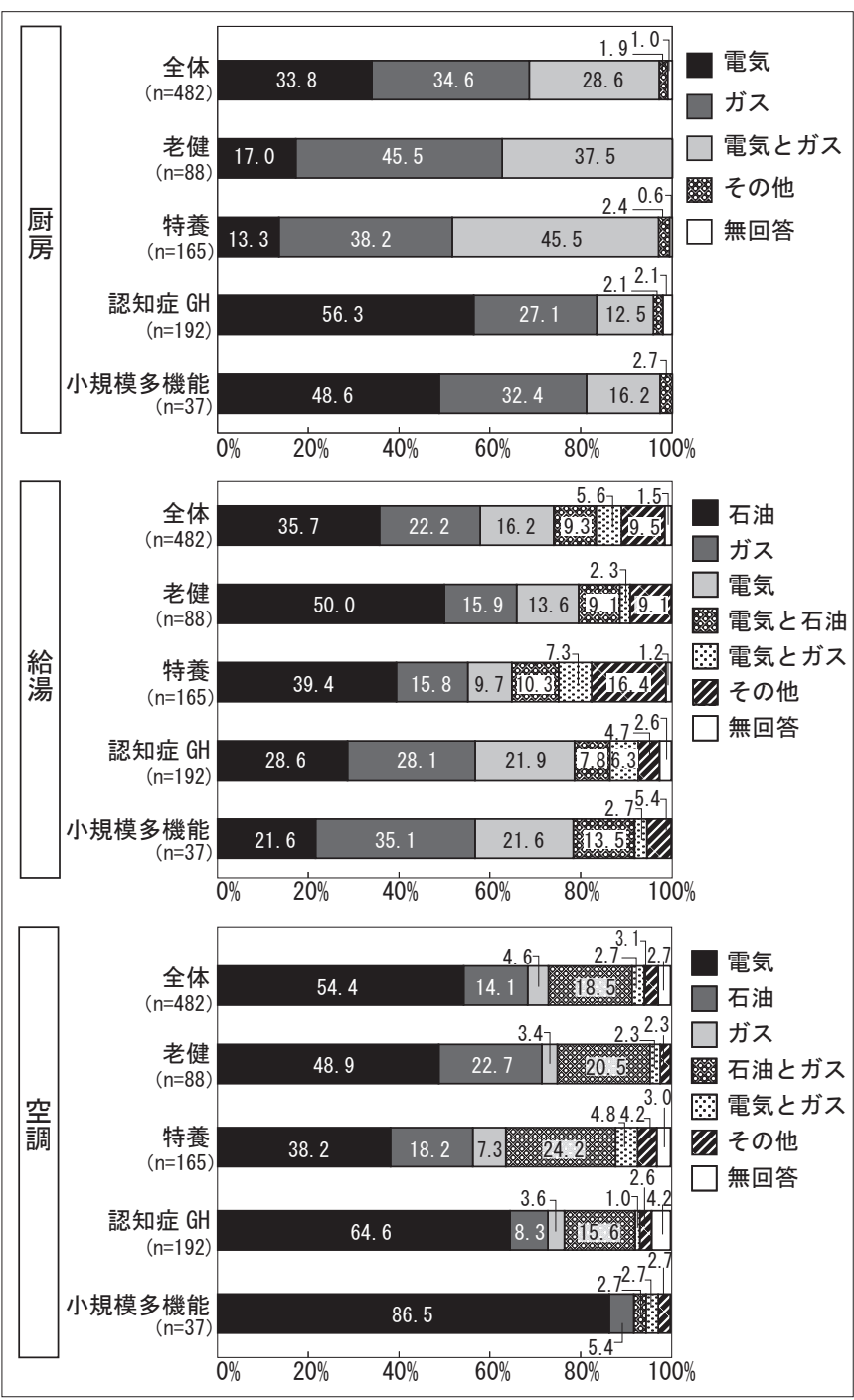

図 14 施設種別にみたエネルギー源

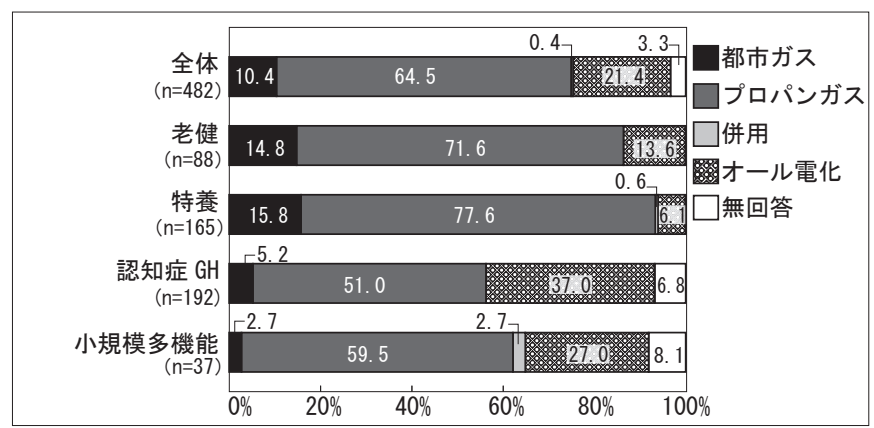

図 15 施設種別にみたガスの種類 

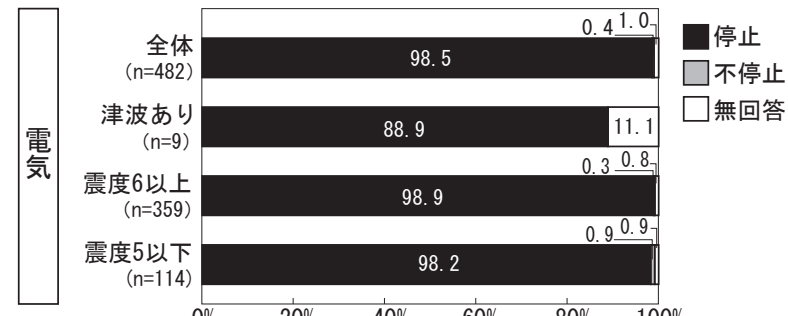

$\square$ 不停止
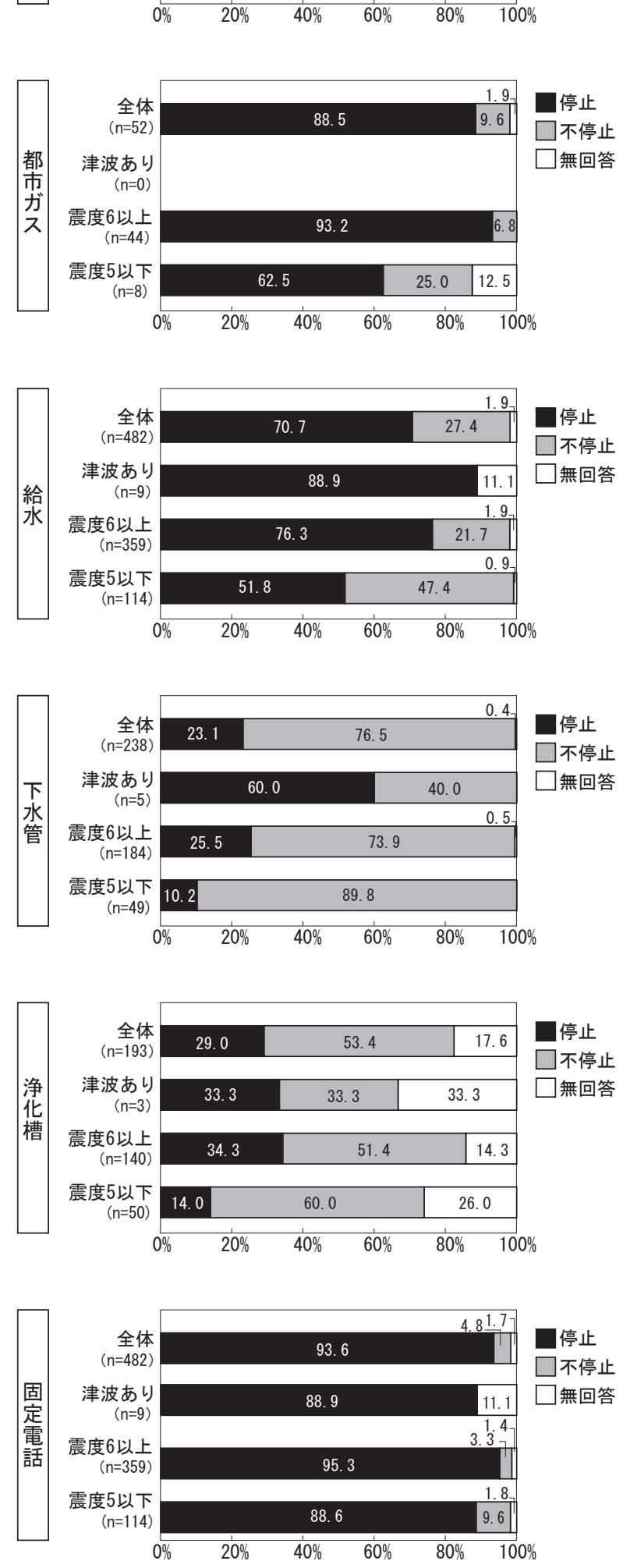

図 16 ライフラインの停止状況
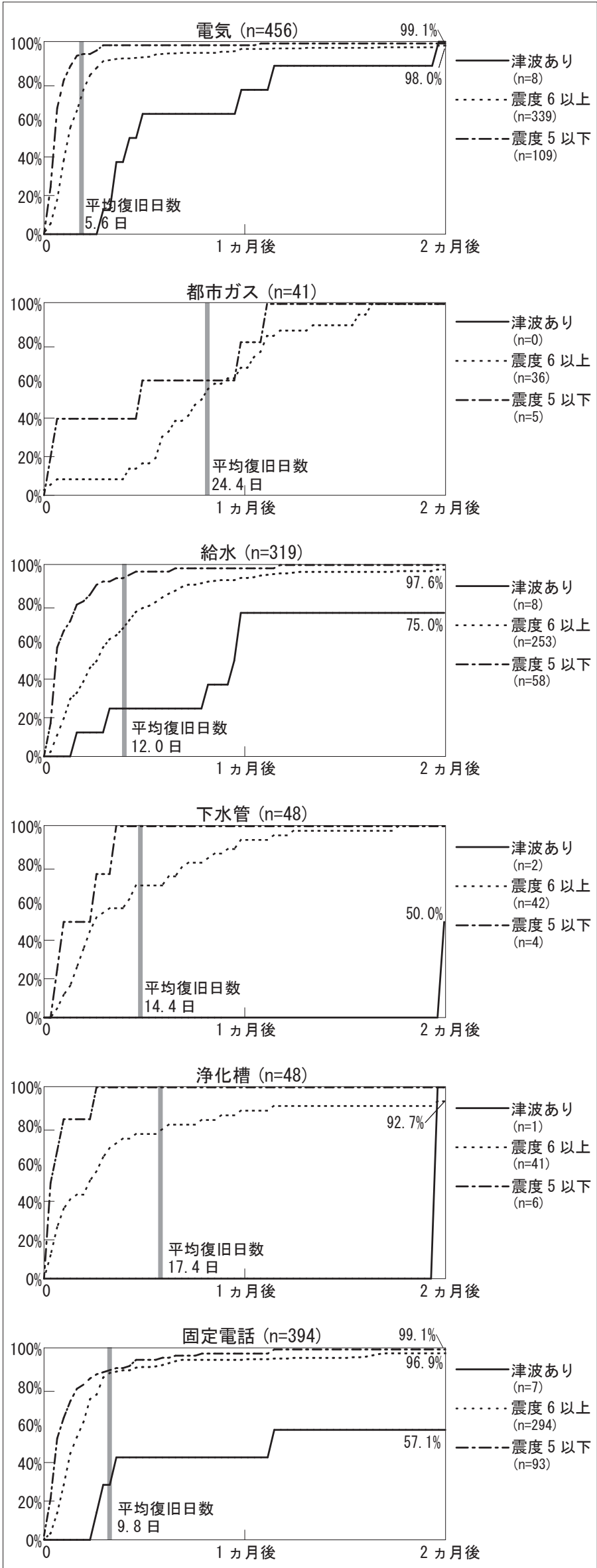

図 17 ライフラインの復旧状況 


\section{【都市ガス】}

都市ガスを使用していた 52 施設の内 46 施設 $(88.5 \%)$ で停止した。 復旧までに要した日数は平均で 24.4 日であった。二週間後に $17.1 \%$ 、 一か月後に $68.3 \%$ の施設で復旧した。

停止率が「震度 6 以上」 $93.2 \%$ 、「震度 5 以下」 $62.5 \%$ 、平均復旧 日数が「震度 6 以上」 25.6 日、「震度 5 以下」16.4 日であり、停止率 および平均復旧日数の両方において差が大きい。

\section{【給水】}

482 施設の内 341 施設 $(70.7 \%)$ で断水した。復旧までに要した日数 は平均で 12.0 日であった。一週間後に約半数の施設で復旧した。他 のライフラインに比べると復旧時期は電気、固定電話に次いで早かっ たが、復旧までに 157 日間要した施設もあり、地域差が大きい。

停止率は「津波被害あり」88.9\%、「震度 6 以上」 $76.3 \%$ 、「震度 5 以下」 $51.8 \%$ 、平均復旧日数は「津波被害あり」 35.6 日、震度 6 以上」 13.0 日、「震度 5 以下」 4.4 日であった。

受水槽を設置している施設は 482 施設の内 276 施設 (57.3\%) であっ た。老健 $97.7 \%$ 、特養 $91.5 \%$ であり、90\%以上の施設で設置され ているのに対し、認知症 GH18.8\%、小規模多機能 $8.1 \%$ であった（図 18)。受水槽を設置していた 276 施設の内 34 施設において、津波等に より震災後に受水槽が使用不可能であった。

断水した施設における水の確保方法は、給水車が $57.2 \%$ 、受水槽 が $39.6 \%$ 、井戸水が $13.2 \%$ であった。給水車、受水槽、井戸水以外で は、川・池・用水路から取水、職員宅から運搬、備蓄や支援物資のペッ トボトル、他事業所から運搬等で対応していた。

\section{【下水】}

下水管に接続していた 238 施設の内 55 施設 $(23.1 \%)$ で停止した。 その内、電気と同じ日に復旧した施設が 16 施設あり、停電によって 浄化施設が機能ダウンあるいは敷地内でポンプアップしている場合 はポンプが停止したためと考えられる。それ以外の施設では、下水管

\begin{tabular}{|c|c|c|c|c|c|c|c|}
\hline & & 電気 & 都市ガス & 給水 & 下水管 & 浄化槽 & 固定電話 \\
\hline \multirow{3}{*}{ 全体 } & 平均 & 5. 6 & 24.4 & 12. 0 & 14. 4 & 17.4 & 9. 8 \\
\hline & 最短 & 0 & 0 & 1 & 2 & 1 & 0 \\
\hline & 最長 & 60 & 50 & 157 & 65 & 157 & 193 \\
\hline \multirow{3}{*}{ 津波あり } & 平均 & 23.0 & - & 35.6 & 48.0 & 60.0 & 55.9 \\
\hline & 最短 & 9 & - & 5 & 31 & 60 & 8 \\
\hline & 最長 & 60 & - & 91 & 65 & 60 & 193 \\
\hline \multirow{3}{*}{ 震度6以上 } & 平均 & 6.1 & 25.6 & 13.0 & 13.6 & 18.5 & 9.9 \\
\hline & 最短 & 0 & 0 & 1 & 2 & 1 & 0 \\
\hline & 最長 & 60 & 50 & 157 & 54 & 157 & 149 \\
\hline \multirow{3}{*}{ 震度5以下 } & 平均 & 2.8 & 16.4 & 4.4 & 6.0 & 2.7 & 5.9 \\
\hline & 最短 & 1 & 1 & 1 & 2 & 1 & 0 \\
\hline & 最長 & 33 & 34 & 36 & 11 & 8 & 116 \\
\hline
\end{tabular}

\begin{tabular}{|c|c|c|c|c|c|}
\hline $100 \%$ & [97. 7] & & & & \\
\hline & 13.6 & \begin{tabular}{|l|}
9.1 .5 \\
9.1 \\
\end{tabular} & & & $\begin{array}{l}\text { あり } \\
\text { (震災後に使用可能) }\end{array}$ \\
\hline $80 \%=$ & & & & & \\
\hline $60 \%-\frac{[57.3]}{7.1}$ & & & & & 士(津波等で使用不可) \\
\hline $40 \%-$ & 84.1 & 82.4 & & & [ ] ]内は合計値 \\
\hline $20 \%-50.2$ & & & [18. 8] & & \\
\hline $\begin{array}{c}\text { 全体 } \\
(\mathrm{n}=482)\end{array}$ & $\begin{array}{l}\text { 老健 } \\
(\mathrm{n}=88)\end{array}$ & $\begin{array}{l}\text { 特㝨 } \\
(\mathrm{n}=165)\end{array}$ & $\begin{array}{c}\text { 認知症 } \\
\text { GH } \\
(\mathrm{n}=192)\end{array}$ & $\begin{array}{l}\text { 小賛模 } \\
\text { 多機能 } \\
(n=37)\end{array}$ & \\
\hline
\end{tabular}

図 18 施設種別にみた受水槽設置割合と被害状沉
が破損したためと考えられる。復旧に要した日数は平均で 14.4 日で あった。

停止率が「津波被害あり」60.0\%、震度 6 以上」25.5\%、震度 5 以下」 $10.2 \%$ であり、全ライフラインの中で最も差が大きい。平均復旧日数

も「津波被害あり」 48.0 日、震度 6 以上」 13.6 日、「震度 5 以下」 6.0 日であり、差が大きい。

浄化槽で污水処理をしていた 193 施設の内 56 施設（29.0\%）で停 止した。全ライフラインの中で停止率が最も低い。停止した 56 施設 の内、電気と同じ日に復旧した施設が 33 施設あり、停電によって浄 化槽のポンプが停止したためと考えられる。それ以外は浄化槽もしく は下水管が破損したためと考えられる。復旧に要した日数は 17.4 日 であった。最も復旧が遅かった施設では 157 日間を要しており、地域 差が大きい。

停止率が「津波被害あり」33.3\%、「震度 6 以上」 $34.3 \%$ 、「震度 5 以下」14.0\%であり差は大きくないが、平均復旧日数は「津波被害あり」 60.0 日、「震度 6 以上」 18.5 日、「震度 5 以下」 2.7 日であり、差が 大きい。

\section{【固定電話】}

482 施設の内 451 施設 $(93.6 \%)$ で固定電話が不通となった。復旧 に要した日数は平均 9.8 日であった。最も復旧が遅かった施設では 193 日間を要しており、地域差が大きい。

停止率が「津波被害あり」88.9\%、「震度 6 以上」95.3\%、「震度 5 以下」

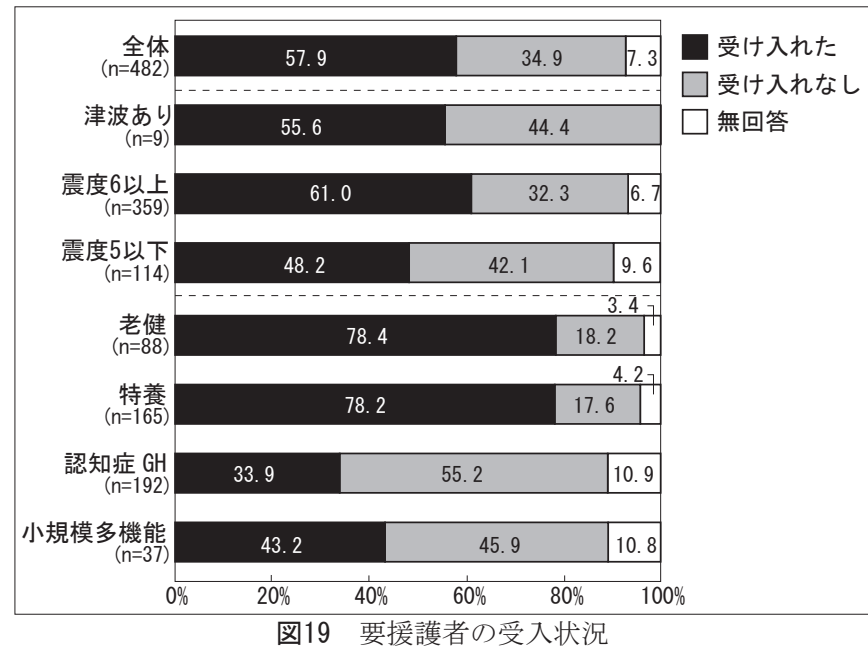

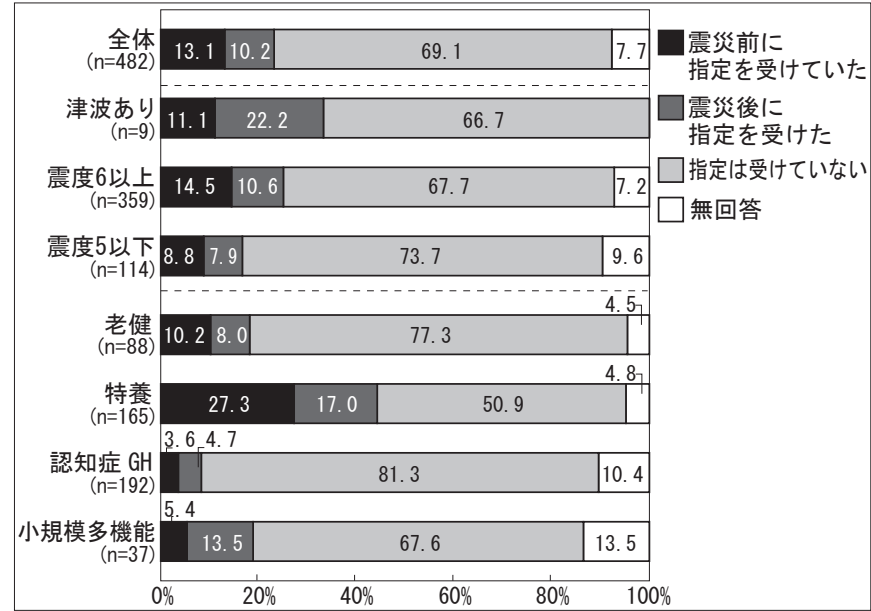

図 20 福祉避難所の指定状況 
$88.6 \%$ であり差はないが、平均復旧日数は「津波被害あり」55.9 日、 「震度 6 以上」9.9 日、「震度 5 以下」5.9 日であり、差が大きい。

\section{7. 防災計画}

\section{1 ) 要援護者への対応}

震災時、高齢者施設は被災を受けつつも地域の要援護者を支援す る役割を求められる。全壊を除く 482 施設の内、279 施設 $(57.9 \%)$ が要援護者を受け入れた。「津波被害あり」が $55.6 \%$ 、「震度 6 以 上」が $61.0 \%$ 、「震度 5 以下」が $48.2 \%$ であった。また、施設種別 による違いが顕著であり、老健 $78.4 \%$ 、特養 $78.2 \%$ に対し、認知症 GH33. 9\%、小規模多機能 $43.2 \%$ であった（図 19）。特養と老健は規模 が大きくスペース的に余裕があること、発災後数日間は居宅サービス の利用が減り、その分の職員を要援護者の受け入れに回すことができ る等、大規模施設であることの利点があるものと推察される。

要援護者をスムーズに受け入れるためには福祉避難所注 4$)$ として の指定を受けていることが重要となるが、全壊を除く 482 施設の 内、63 施設 $(13.1 \%)$ が震災前に指定を受けていた。「津波被害あり」 が $11.1 \%$ 、「震度 6 以上」が $14.5 \%$ 、「震度 5 以下」が $8.8 \%$ であっ た。また、特養で $27.3 \%$ 、老健が $10.2 \%$ 、小規模多機能で $5.4 \%$ 、 認知症 GH で $3.6 \%$ であった。「震災後に指定を受けた」のは特養で $17.0 \%$ 、小規模多機能で $13.5 \%$ 、老健で $8.0 \%$ 、認知症 GH で $4.7 \%$ であった（図 20）。

\section{2 ) 非常用設備の確保}

\section{【非常用予備電源】}

保安用に使用寸る非常用予備電源を整備している施設は 482 施設 の内 77 施設 $(16.0 \%$ ) であり、老健 $27.3 \%$ 、特養 $22.4 \%$ に対して、 認知症 GH6. $8 \%$ 、小規模多機能 $8.1 \%$ であった。防災設備専用の非常 用予備電源を整備している施設は 210 施設 $(43.6 \%)$ であり、老健 $58.0 \%$ 、特養 $61.2 \%$ と過半の施設で整備されていたのに対し、認知 症 GH24.5\%、小規模多機能 29.7\% であった。保安用と防災設備専用 を合計すると、非常用予備電源は 287 施設 $(59.5 \%)$ で整備されていた。 非常用予備電源を整備していない施設は老健と特養では約 $10 \%$ であっ たが、認知症 GH と小規模多機能では半数を超していた（図 21）。

\section{【小型発電機】}

非常用の小型発電機を保有していた施設は 482 施設の内 148 施 設 $(30.7 \%)$ であった。老健 $45.5 \%$ 、特養 $47.3 \%$ に対して、認知症 GH13.0\%、小規模多機能 $13.5 \%$ であった（図 22）。

\section{3) 物品の備蓄状況}

各物品を備蓄している施設の割合は、「食糧」 $88.0 \%$ 、「おむつ」 $78.8 \%$ 、「飲料水」 $72.2 \%$ 、「医薬品」 $60.6 \%$ 、「コンロ」 $54.1 \%$ 、「燃料」 47. 9\%であった（図 23）。また、「プロパンガス」を使用していた 313
施設の内 219 施設（70.0\%）が「プロパンガス」を備蓄していた。給 水が停止した施設が 341 施設あり、その内飲料水を備蓄していた施設 が 272 施設 $(79.8 \%)$ であった。

備蓄していた施設に限定して各物品の平均備蓄日数をみると、「食 糧」が 3.3 日、「飲料水」が 3.8 日、「燃料」が 8.6 日、「おむつ」が 9.2 日、「医療品」が 10.0 日であった（表 6)。給水の復旧日と飲料水 の備蓄日数に回答のあった 245 施設についてみると、飲料水の備蓄日 数が給水停止日数を越えていたのは 37 施設（15.1\%）のみであった。

地震発生後の必要物調達方法について子予め関係業者と調達計画を 策定していたのは 8.7\% であり、どの施設種別においても10\%未満で あった。

\section{4 ）防災マニュアルと避難訓練}

火災を想定した防災マニュアルの策定率はいずれの施設において もほぼ 100\%、地震を想定した防災マニュアルの策定率は 70.3\%であっ た。津波を想定した防災マニュアルを策定していたのは $3.5 \%$ にた る 17 施設のみであり、その内訳は老健 2 施設、特養 5 施設、認知症 GH8 施設、小規模多機能 2 施設であった（図 24)。「津波被害あり」(全 壊除く）の 9 施設についてみると、策定 2 施設、未策定 6 施設、無回 答 1 施設であった。

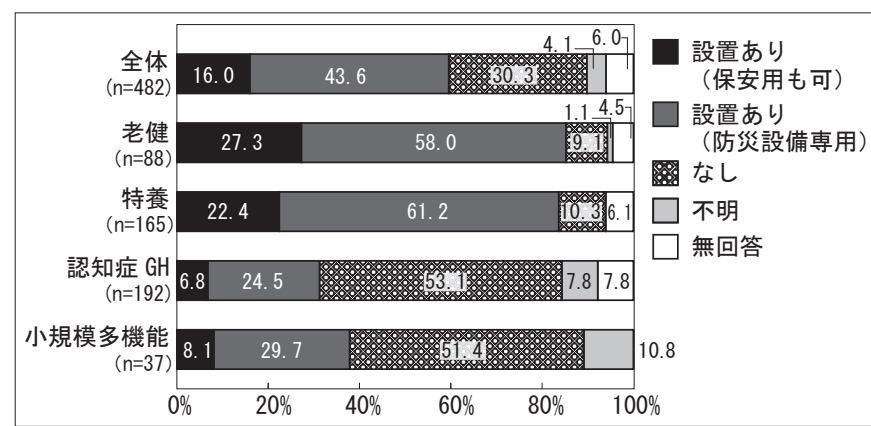

図 21 施設種別にみた非常用予備電源の設置状況

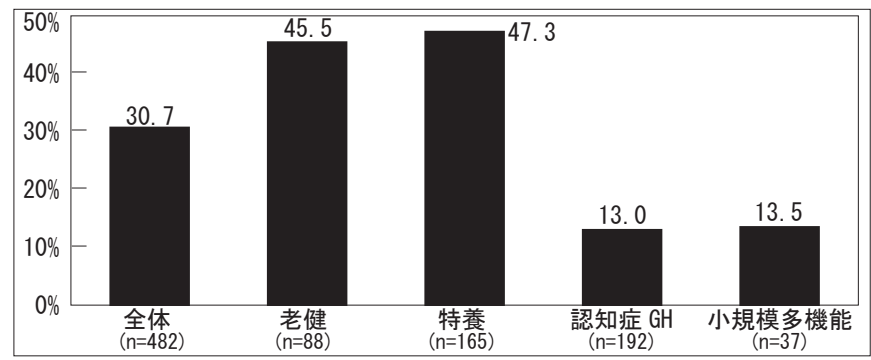

図 22 施設種別にみた非常用小型発電機の保有状況

\begin{tabular}{|c|r|r|r|r|r|}
\multicolumn{2}{c|}{ 表 6} & \multicolumn{1}{c|}{ 備蓄の平均・最短・最長日数 } \\
\hline & $\begin{array}{c}\text { 食糧 } \\
(n=396)\end{array}$ & $\begin{array}{c}\text { おむつ } \\
(n=332)\end{array}$ & $\begin{array}{c}\text { 飲料水 } \\
(n=328)\end{array}$ & $\begin{array}{c}\text { 医療品 } \\
(\mathrm{n}=217)\end{array}$ & $\begin{array}{c}\text { 燃料 } \\
(\mathrm{n}=174)\end{array}$ \\
\hline 平均 & 3.3 & 9.2 & 3.8 & 10.0 & 8.6 \\
\hline 最短 & 1 & 1 & 1 & 1 & 1 \\
\hline 最長 & 14 & 60 & 100 & 180 & 45 \\
\hline
\end{tabular}

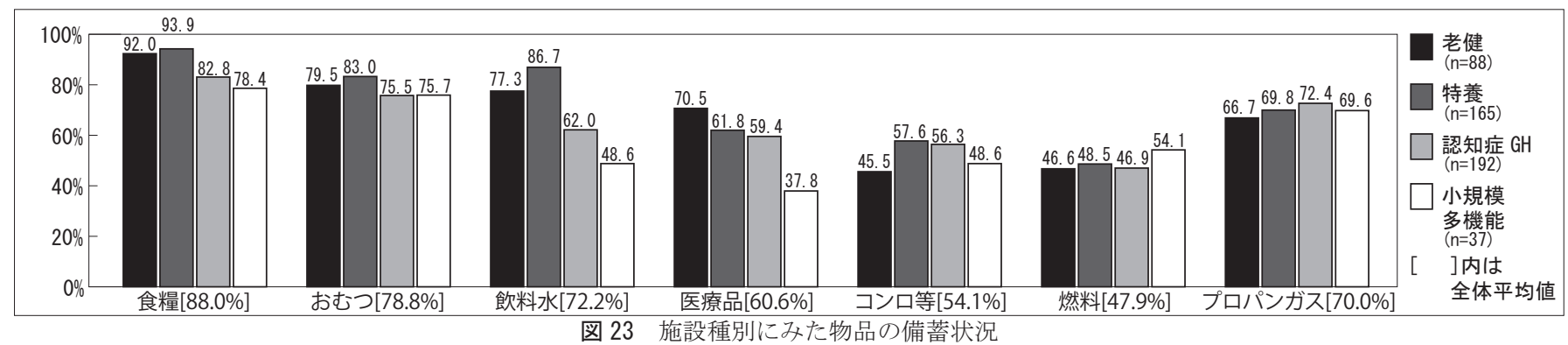


避難訓練ついても同様の傾向がみられ、火災を想定した避難訓練は 97. 7\% の実施率であったが、地震を想定した避難訓練は $47.3 \%$ であり、 津波を想定した避難訓練は岩手県大船渡市にある認知症 $\mathrm{GH} 1$ 施設のみ で実施されていた（図 25）。「津波被害あり」（全壊除く）の9施設で 津波を想定した避難訓練を実施していた施設はなかった。

5 ）災害発生時の設備管理マニュアル

災害発生直後の設備関係の管理マニュアルを策定していた施設は 39. 8\% であった（図 26）。

\section{8. まとめ}

\section{1 ) 被災状況}

震度についてみると、震度 6 以上が全施設の $3 / 4$ を占めた。沿岸部 市町村では震度 6 強以上の割合が高い。31 施設が津波の被害に遭い、 沿岸部市町村に立地する施設の $18.7 \%$ にあたる。人的被害（死亡・ 行方不明）があったのは 12 施設であり、利用者に被害のあった全施 設が床上浸水の被害を受けていた。

\section{2) 建物被害}

95. $4 \%$ の施設で何らかの建物被害があった。「建物内の亀裂・落下」、 「外壁の亀裂」「建具や家具の破損」、「屋内設備の破損」、地盤被害」、 「屋外設備の破損」、構造体の被害」の順に被害が大きかった。津波 の有無によって建物被害は顕著に異なり、「構造体の被害」では 13 倍、 「屋外設備の破損」「屋内設備の破損」では 3 倍以上、「地盤被害」「建 具や家具の破損」で 2 倍以上の開きがあった。津波被害のなかった施 設についてみると、「震度 6 以上」の施設は「震度 5 以下」の施設に 比べて被害が大きく、「地盤被害」では 4 倍以上、「構造体の被害」「屋 外設備の破損」「建具や家具の破損」では 3 倍以上、「外壁の亀裂、「屋 内設備の破損」では 2 倍以上の開きがあった。特に老健および特養に おいて震度による建物被害の差が大きい。「地盤被害」は土地造成と 関連性があり、土地造成が多くなされている老健や特養で「地盤被害」 の割合が高かった。

「全壊」が 22 施設（4.4\%)、「半壊」が 18 施設（3.6\%）であった。 全壊した 22 施設全てが津波の被害を受けており、津波被害の割合が 高い小規模多機能において「全壊」の割合が高かった。全壊判定を受 けた施設の被災後の事業継続をみると、「事業継続」8施設、「一旦休 止後事業再開」 7 施設、「事業休止」 6 施設、「事業廃止」 1 施設であった。

\section{3 ） ライフラインの停止と復旧}

ライフラインの停止率は、大きい順に電気、固定電話、都市ガス、 給水、浄化槽、下水管であった。復旧までの平均日数は、都市ガスが 最も長く、次いで浄化槽、下水管、給水、固定電話、電気であった。 一方、復旧までの最長日数をみると、給水および浄化槽では 157 日間、 固定電話では193 日間を要した施設があり、地域差が大きい。「津波 被害あり」「震度 6 以上」「震度 5 以下」の順に停止率が高く平均復旧 日数が長いが、停止率では「下水管」において、平均復旧日数では「固 定電話」「電気」「下水管」において差が大きい。

\section{4 ) 防災計画}

地域の要援護者を受け入れる福祉避難所のあり方は今後の防災計 画において重要となる。今回の震災では 279 施設 $(57.9 \%)$ が要援護 者を受け入れており、特に老健と特養での受入率が高い。老健・特養 等の大規模施設と認知症 $\mathrm{GH}$ ・小規模多機能等の小規模施設では、地 域において果たすべき役割や可能となる対応が異なることも考えら

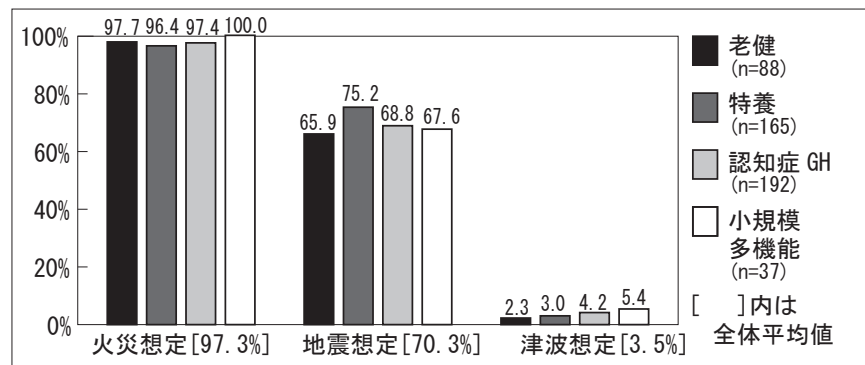

図 24 施設種別にみた防災マニュアルの策定状況
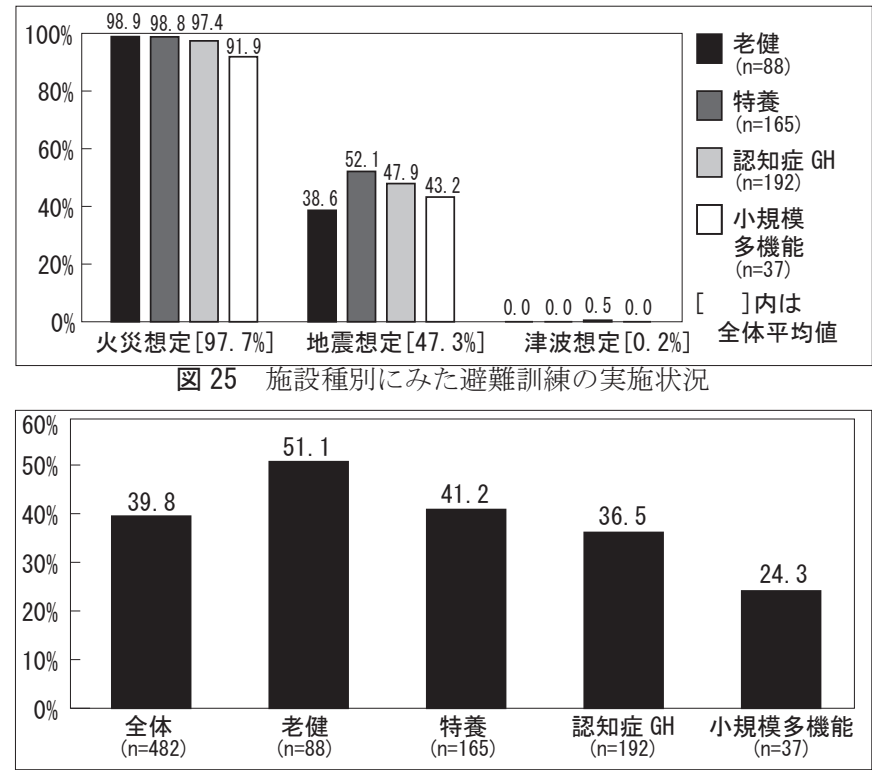

図 26 施設種別にみた災害発生時の管理マニュアルの策定状況

れる。自治体や自治会と連携しながら、地域の防災計画の中で、各施 設の役割を検討しておく必要がある。

非常用予備電源の整備率は老健と特養で $84.2 \%$ 、認知症 $\mathrm{GH}$ と小規 模多機能で $32.3 \%$ 、小型発電機の整備率は老健と特養で $46.6 \%$ 、認 知症 GH と小規模多機能で $13.1 \%$ であり、老健と特養において非常用 設備の整備率が高かった。ライフラインが復旧寸るまで最低限の生活 を継続させるためには、非常用設備の整備が必要である。

備蓄率をみると高い順に「食料」「おむつ」「飲料水」「プロパンガス」 「医療品」「コンロ」「然料」であった。平均備蓄日数をみると、「飲料水」 と「食料」が約 3 日分、「おむつ」「医療品」「然料」が約 10 日分であっ た。施設の立地や規模、また災害の規模や状況によっては、入居者だ けではなく帰宅困難となる職員や地域住民も一時的に受け入れる事 態も想定される。また備蓄のあり方は、物資の流通・供給再開時期と も関連があるため災害の規模や立地によっても考え方が変わってく る。各施設の置かれている状況に応じて柔軟に備蓄計画を検討するこ とが必要である。

火災を想定した防災マニュアルはほぼ 100％、地震を想定した防災 マニュアルは $70.3 \%$ であったのに対し、津波を想定した防災マニュ アルの策定率は $3.5 \%$ にある 17 施設のみであった。「津波被害あり」 (全壊除く) の 9 施設についてみると、策定 2 施設、未策定 6 施設、 無回答 1 施設であった。避難訓練ついても同様の傾向がみられ、津波 を想定した避難訓練を実施していたのは 1 施設のみであった。「津波 被害あり」(全壊除く) の 9 施設で津波を想定した避難訓練を実施し ていた施設はなかった。防災マニュアルおよび避難訓練が十分ではな 
い状況が明らかになったが、今後は最悪を想定した中での防災マニュ アルの策定と避難訓練の実施、設備管理マニュアルの策定を再検討寸 る必要がある。

\section{5 ）施設種別の被害状況と防災計画からみた対策に関する考察}

「老健と特養」、認知症 GH と小規模多機能」に分けて、被害状況と 防災計画の現状を踏まえて今後の対策について考察する。

\section{【老健と特養】}

老健と特養では、認知症 GH と小規模多機能に比べて「地盤被害」「外 壁の亀裂」「屋外設備の破損」「屋内設備の破損」における被害の割合 が高かった。「地盤被害」は土地造成との関連性がみられ、老健と特 養で土地造成が多くなされていた。大規模施設では造成を伴う施設計 画にならざるを得ない状況もあるが、敷地の選定および建築時におけ るリスクの把握と対策が重要である。

老健と特養では、認知症 GH と小規模多機能に比べて非常用予備電 源や小型発電機の整備率が高かったものの、保安用にも使用可能な予 備電源を設置している施設は 3 割に満たず、また小型発電機も過半の 施設で整備されていない。疢の吸引や在宅酸素等の医療機器一の電力 の供給を考えると、特に医療的処置が必要な要介護高齢者が多く入居 するこれらの施設では非常用設備の整備が不可欠である。

また、老健と特養の 8 割近くが震災後に要援護者を受け入れた。福 祉避難所の指定を受けた施設は少なかったが、今後は福祉避難所の指 定を受けて行政との連携の中で防災拠点として機能することが求め られるであろう。

\section{【認知症 GH と小規模多機能】}

小規模多機能で津波被害の割合が高く、これは民家が多くあるまち なかに立地していたためと推察される。

エネルギー源についてみると、認知症 GH と小規模多機能では、「欴 房」と「空調」において単一の熱源に頼る施設の割合が高かった。また、 オール電化の施設が認知症 GH で $37.0 \%$ 、小規模多機能で $27.0 \%$ あっ た。今回の震災のようにライフラインの停止が長期間に及ぶ場合を想 定すると、複数の熱源の確保が望ましい。

また、認知症 GH と小規模多機能では、非常用予備電源や小型発電機 等の非常用設備の整備率が低かったので、これらの整備も求められる。

\section{今後の課題}

今回の震災では道路の分断や燃料不足等により施設への物資の供 給が滞ったが、本調查では物資供給の再開時期に関する質問項目を設 定していなかった。また、一法人一施設運営と一法人複数施設運営で は発災時・避難時・復旧時における対応が分かれると予測されるが、 本調査では明らかにすることができなかった。これらについては、ア ンケート調査と並行して実施した現地ヒアリング調查の結果も踏ま えて明らかにすることを今後の課題としたい。

\section{謝辞}

調査にご協力いただいた岩手県保健福祉部長寿社会課、宮城県保健 福祉部ならびにアンケート調査にご回答いただいた施設スタッフの 方々にここに記して感謝を表します。

平成 23 年度厚生労働省老人保健事業推進費等補助金事業を受け一 般社団法人日本医療福祉建築協会が調查研究を実施し、東日本大震災 における高齢者施設の被災実態に関する調査研究報告書としてまと めた。研究は、悉皆アンケート調査、現地ヒアリング調查、後方支援
調查の 3 つの調查により構成されており、本稿は悉皆アンケート調査 部分の報告である。下記の 21 名の研究者および建築実務者により調 查が実施された。石井敏（全体統括）、井上由起子、三浦研、生田京子、 大原一興、狩野徹、神吉優美、橘弘志、山口健太郎、山本和恵、井上 博文、合田淳平、安藤繁、菅野正広、酒巻佳江、鈴木慶治、新澤悦夫、 早坂孝康、茂木聡、三浦雅博、山崎敏。

注

注 1）参考資料 1 から参考表 1 を抜粋した。

注 2）本研究では、沿岸部および内陸部市町村を参考表 2 のように分類した。

注 3)ここでいう「津波被害あり」は、アンケート調査の津波被害の有無に関 する設問に対して、「床下浸水」「1 階床上浸水」「2 階以上床上浸水」のいず れかを選択した施設である。786 施設中、有効回答の得られた 504 施設に対 する数と割合であり、実際にはこれ以上の施設で津波の被災があったものと 推察される。

注 4）福祉避難所の対象として、高齢者、障害者、妊産婦、乳幼児、病弱者等 避難所生活において何らかの特別な配慮を必要とする者 (以下、要援護者) が想定されている。平常時に福祉避難所の指定を受けることにより、要援護 者への福祉避難所に関寸る情報周知、福祉避難所として機能寸るための施設 整備（施設のバリアフリー化や情報関連機器の設置等）、必要な物資や器材 の備蓄、運営体制の事前整備、要援護者支援対策に関寸る研修会や勉強会へ の参加が可能となる。また、災害時には要援護者の迅速な福祉避難所への入 所、混乱の回避、スムーズな事務手続き、優先的物資の供給が可能となる等 の利点がある。（参考文献 7)

\section{参考文献}

1）厚生労働省老健局第 3 回災害医療等のあり方に関寸る検討会資料 1 (http:// www. mh1w. go. jp/stf/shingi/2r9852000001q8my-att/2r9852000001q8of. pdf)、2012 年 6 月 4 日参照

2) 公益社団法人全国老人福祉施設協議会 : 災害時における特別養護老人ホーム のリスクマネジメント調査研究事業報告書、2012.3

3）株富士通総研：被災時から復興期における高齢者への段階的支援とその体 制のあり方の調査研究事業報告書、2012. 3

4）公益社団法人日本認知症グループホーム協会 : グループホームにおける災 害時対策に関する研究報告書、2012.3

5）永家忠司，外尾一則，北川慶子，猪八重拓郎：東日本大震災の被災地域にお ける社会福祉施設の立地特性について、土木計画学研究・講演集、vol. 44、 CD-ROM、2011. 11

6）井上由起子、神吉優美、石井敏: 高齢者施設の被災実態に関する悉皆アンケー 卜調査の結果報告〜東日本大震災における高齢者介護施設の被災実態に関す る調査報告その 1 ～、日本建築学会大会学術講演梗概集 E、pp. 29-32、2012.9

7）厚生労働省：福祉避難所設置・運営に関するガイドライン、2008.6

参考表 1 東日本大震災による高齢者等の被災状況について

\begin{tabular}{|c|c|c|c|c|c|}
\hline \multirow{2}{*}{ 施設種別 } & \multirow{2}{*}{$\begin{array}{l}\text { 被災施設数 } \\
\text { (全壊·半壊) }\end{array}$} & \multicolumn{2}{|c|}{ 死亡者数 } & \multicolumn{2}{|c|}{ 不明者数 } \\
\hline & & 入居者 & 職員 & 入居者 & 職員 \\
\hline 特別養護老人ホーム & 11 & 170 & 19 & 41 & 60 \\
\hline 養護老人ホーム & 2 & 48 & 24 & 2 & 0 \\
\hline 軽費老人ホーム & 5 & 21 & 1 & 2 & 3 \\
\hline 介護老人保健施設 & 6 & 137 & 9 & 26 & 48 \\
\hline 介護療養病床 & 1 & 0 & 0 & 0 & 0 \\
\hline 認知症 G H & 27 & 31 & 5 & 7 & 4 \\
\hline 合計 & 52 & 407 & 58 & 78 & 115 \\
\hline
\end{tabular}

※福島県で被災したグループホーム入居者は、同一敷地内の老健に避難中に津波を受けたた め、死亡者数及び不明者数は老健に計上している。

参考表 2 沿岸部市町村と内陸部市町村の分類

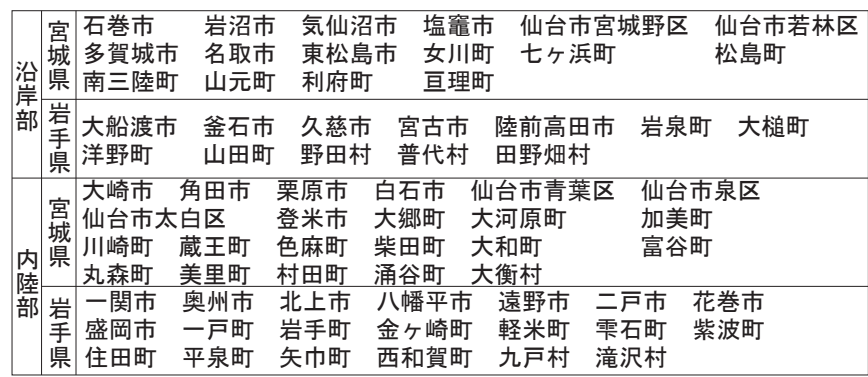

（2012年 7 月 8 日原稿受理， 2013年 5 月 31 日採用決定） 